\title{
EDAPHO-CLIMATIC ZONING FOR EUCALYPTUS UROGRANDIS IN THE STATE OF TOCANTINS, BRAZIL
}

\section{ZONEAMENTO EDAFOCLIMÁTICO PARA O EUCALYPTUS UROGRANDIS NO ESTADO DO TOCANTINS}

\author{
Olíria Morgana Menezes SOUZA ${ }^{[1]}$, Erich COLLICCHIO ${ }^{[1]}$, Eduardo Quirino PEREIRA ${ }^{[1]}$ and Maria Inês Ramos AZEVEDO ${ }^{[1]}$ \\ ${ }^{[1]}$ Federal University of Tocantins (UFT). Ave. NS 15 ALC NO 14, 109 Norte. CEP 77.001-090, Palmas-TO, Brazil. collicchio.e@gmail.com; \\ eduquirino@gmail.com; inesramosaz@gmail.com
}

*Corresponding author: oliria.eng.amb@gmail.com

\begin{tabular}{|c|c|}
\hline RTI & ABSTRACT \\
\hline & \multirow{12}{*}{$\begin{array}{l}\text { Edaphic and climatic zoning was undertaken in the State of Tocantins for } \\
\text { eucalyptus crop in the State of Tocantins, in particular, Eucalyptus urograndis using } \\
\text { ArcGIS } 9.3 \text { platform, a geographic information system (GIS) tool for working with } \\
\text { maps. Thus, the study was based on the parameters that reflect the climatic } \\
\text { requirements for the proper development of the species, natural edaphic aptitude } \\
\text { and the slope of the land for crop mechanization purposes. The first phase of the } \\
\text { study comprised the cross-checking of maps of precipitation, temperature and } \\
\text { water deficit, which resulted in the zoning of climatic aptitude. The second phase } \\
\text { comprised the zoning of natural edaphic aptitude, based on existing soil units in } \\
\text { the state. Based on the results obtained an edaphic and climate zoning was } \\
\text { performed for the species to. The findings showed temperature constraint to the } \\
\text { development of Eucalyptus urograndis. However, they stress the importance of the } \\
\text { present study regarding the clones that are being implemented in Tocantins. } \\
\text { Concerning natural edaphic aptitude, there was a predominance of soils } \\
\text { considered unfavorable, yet significant areas were found to have favorable soil } \\
\text { aptitude. }\end{array}$} \\
\hline & \\
\hline Iblish & \\
\hline ocument $C$ & \\
\hline & \\
\hline or: & \\
\hline $15 @$ & \\
\hline BFSO & \\
\hline ble t & \\
\hline & \\
\hline 036 & \\
\hline & \\
\hline
\end{tabular}

JBFS all rights (BY NC SA)

Keywords: Agro-ecological aptitude, Geographic information system, Geotechnology

\begin{abstract}
RESUMO - Foi realizado o zoneamento edafoclimático para a cultura do eucalipto no Estado do Tocantins, em específico para o Eucalyptus urograndis, utilizando uma ferramenta do sistema de informações geográficas, ambiente ArcGIS 9.3. Para isso, o estudo baseou-se nos parâmetros que refletem as exigências climáticas para o bom desenvolvimento da espécie, a aptidão edáfica natural e a declividade do solo para fins de mecanização da cultura. Na primeira fase do trabalho fez-se o cruzamento dos mapas básicos de precipitação, temperatura e déficit hídrico, que resultou no zoneamento de aptidão climática. Na segunda fase gerou-se o zoneamento de aptidão edáfica natural, com base nas unidades de solos existentes no Estado. A partir dos resultados obtidos elaborou-se o zoneamento de edafoclimático para a espécie. Os resultados mostraram que há uma restrição térmica para o desenvolvimento desta espécie, contudo reforça a importância do estudo em questão aos clones que estão sendo implantados no Estado. No que se refere à aptidão edáfica natural, observou-se um predomínio de solos considerados desfavoráveis, contudo notaram-se áreas significativas com aptidão favorável.
\end{abstract}

Palavras-chave: aptidão agroecológica, sistema de informações geográficas, geotecnologia.

Funding: The authors have no support or funding to report

Competing interests: The authors have declared that no competing interests exist.

How to refer to this document (ABNT):

SOUZA, O. M.; COLLICCHIO, E.; PEREIRA, E. Q.; AZEVEDO, M. I. R. Edapho-climatic zonig for Eucaliptus urograndis in the State of the Tocantins, Brazil. Journal of Bioenergy and Food Science, Macapá, v.2, n.2, p.62-71, abr./jun. 2015. DOI: 10.18607/jbfs.v2i2.36 


\section{INTRODUCTION}

In Brazil, Eucalyptus plantations are widely used for reforestation in the north and south of the country. In the past few years there has been a growth in plantations since the silvicultural characteristics of the eucalyptus make it easily adaptable to the Brazilian soil, and as a consequence several species are being introduced (SILVA et al., 2006).

The main explanation for the fast expansion of eucalyptus plantations in the Cerrado is that the species were planted in low-cost land previously used in extensive livestock farming, with degraded pastures, and the presence of large national paper pulp mills. Although the soil and climate conditions in the Cerrado favor the growth of eucalyptus plantations, the soils may have a very low natural fertility. However, eucalyptus has been intensely cultivated in the area (RESIS et al., 1985).

The quality of wood, as well as the speed of growth, the longevity of the plants and the shape of the stem will depend on the quality of the soil, and water retention capacity to regulate nutrient uptake by plants is very important. The trees grow well in regions where rainfall ranges from 900 to $2000 \mathrm{~mm}$. Thus, several areas of Tocantins are suitable for the development of eucalyptus species. The highest yields are reported in regions not affected by water deficit (MORA; GARCIA, 2000).

The eucalyptus species currently grown in Brazil are Eucalyptus camaldulensis, Corymbia citriodora, E. grandis, E. robusta, E. saligna, E. globulus, E. deglupta, E. tereticornis, E. pellita, E. moorei, E. smithii, E. urophylla and E. resinifera. In addition to these, hybrid species such as Eucalyptus urograndis (E. grandis $\times$ E. urophylla) $(\mathrm{CIB}, 2008)$ are also developed.

The present study aimed to identify potential areas of edaphic and climatic aptitude for species Eucalyptus urograndis (hybrid Eucalyptus urophylla S.T. Blake X Eucalyptus grandis W. Hill ex Maiden) with the purpose of planting eucalyptus in the state of Tocantins. Water balance analysis associated to the crop needs was also performed.

\section{Material and methods}

The study area comprised the state of Tocantins (Figure 1), located in the Northern region of Brazil, with a total area of $277.620,914 \mathrm{~km}^{2}$, composed of 139 cities and a population of 1,383,455 inhabitants (SEPLAN, 2012a; IBGE, 2012).

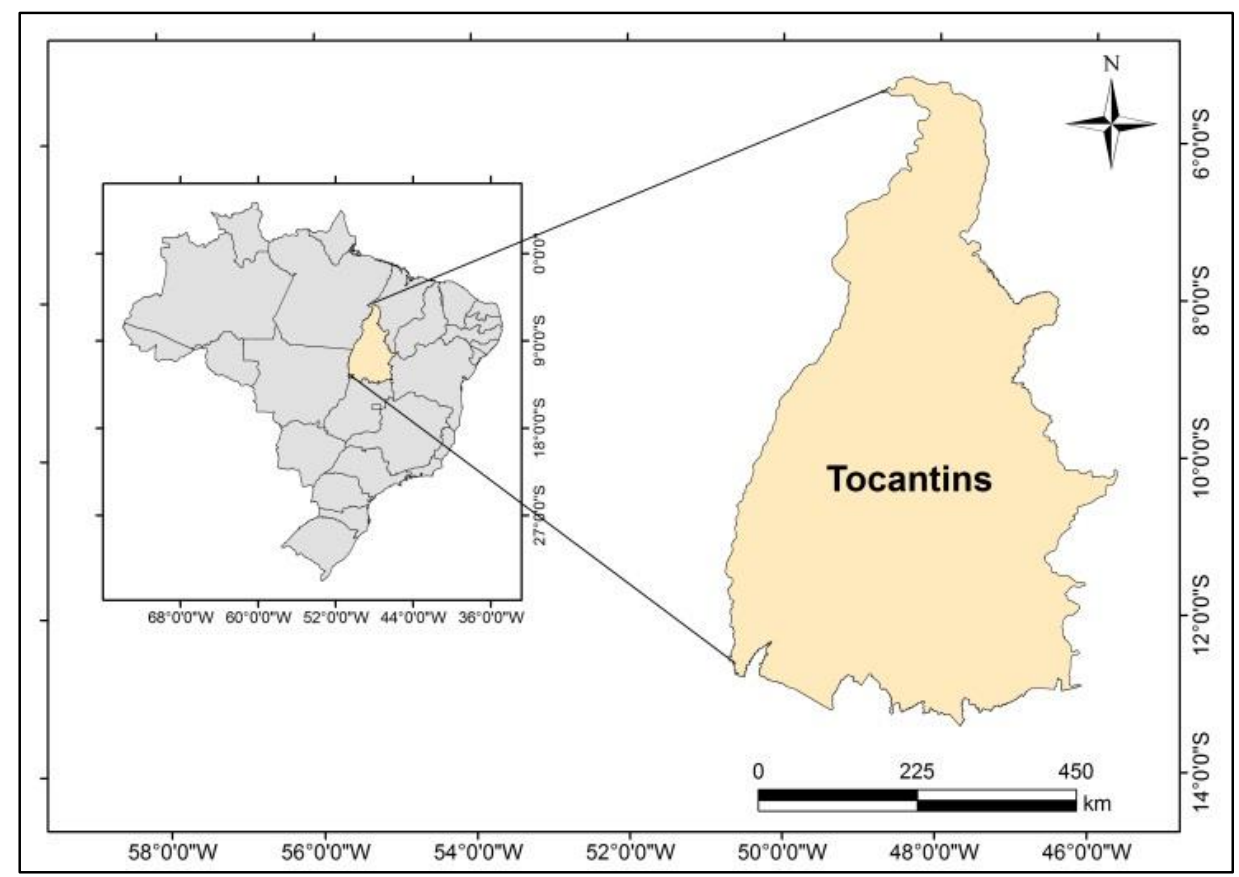

Figure 1. Geographical location of the State of Tocantins, Brazil.

Calculation of the water balance through the Thornthwaite and Mather method (1955) was performed using the database of 110 weather stations with rain gauge data, organized by Collicchio (2008). For this calculation, an electronic spreadsheet developed by Pereira (2005) was used, and an available water capacity (CAD) of $300 \mathrm{~mm}$ was adopted (STAPE; GOMES, 1996; NEVES, 2000).

Spline interpolation method for spatial distribution of climatic variables was used, with the aid of ArcGIS 9.3 software, which led to the 
generation of the maps of rainfall, temperature and water deficit.

Each climatic variable was reclassified as "Apt" or "Inapt" according to the aptitude or aptitude threshold required by each species. After the cross-section of climatic variables, two additional classes can be obtained, namely the classes "Marginal" and "Restricted" described in Table 1. This table shows the climatic characteristics required by the species Eucalyptus urograndis, according to Sperandio et al. (2010).

Table 1. Classes of climatic aptitude of the species Eucalyptus urograndis.

\begin{tabular}{|c|c|c|c|}
\hline $\begin{array}{l}\text { Climatic } \\
\text { Aptitude }\end{array}$ & Annual Average Temperature $\left({ }^{\circ} \mathrm{C}\right)$ & Annual Water Deficit (mm) & Annual Rainfall (mm) \\
\hline Apt & $18<\mathrm{T}<25$ & $15<\mathrm{Da}<170$ & $720<P<1800$ \\
\hline Inapt & $\mathrm{T}<19$ or $\mathrm{T}>25$ & $\mathrm{Da}<15$ or $\mathrm{Da}>170$ & $\mathrm{P}<720$ or $\mathrm{P}>1800$ \\
\hline Marginal & \multicolumn{3}{|c|}{ Occurrence of at least two climatic variables considered "apt" } \\
\hline Restricted & \multicolumn{3}{|c|}{ Occurrence of only one climatic variable considered "apt" } \\
\hline
\end{tabular}

Source: Sperandio et al. (2010)

The map of agro-climatic zoning was generated by multiplication of the grids, precipitation, temperature and water deficit related to Table 1, according to the method of Nappo et al. (2005). The same occurred with the edaphic zoning after the raster format files of the parameters proposed for the study were obtained.

Based on the pedology file in a shapefile provided by the Department of Planning of Tocantins and the updated Geographic Database (SEPLAN, 2012b) it has been possible to identify the types of soil of each city.

The interpretation of classes of soils for generation of edaphic zoning was especially developed for the present study, considering the attributes natural fertility, depth, stoniness, drainage and slope. Each class of soil was classified as shown in Chart 1.

Some criteria analyzed for natural fertility correlated to base saturation (\%) were obtained in the report of SEPLAN (2004), calculating the average of a B horizon of each soil.

Weights were established for each soil parameter as follows: low $=1$ and high $=5$, with means ranging from 2 to 4 , as shown in Chart 1 .

Relief study is essential to support the use of agricultural machinery and provide information on susceptibility to erosion. With the use of the slope file, in shapefile format provided by SEPLAN (2012b) weight values were considered for each slope class, where the higher the slope (Table 2), the greater the difficulty in obtaining agricultural mechanization.

Table 2. Reclassification of slope aiming to agricultural mechanization.

\begin{tabular}{lccc}
\hline \multicolumn{1}{c}{ Classes } & SEPLAN & Slopes (\%) & Weight \\
\hline Easily Mechanizable & A & $0-5$ & 5 \\
Mechanizable & B, AB, BA & $5-12$ & 4 \\
Moderately Mechanizable & C, BC, CB & $12-18$ & 3 \\
Not Mechanizable & D, DC, CD, E, F & $>18$ & 1 \\
\hline
\end{tabular}

Source: Adapted from SEPLAN (2012b) apud Collicchio (2008)

The results of the cross-checking of the data analyzed for the 21 types of soils that compose the state of Tocantins were reorganized in the following classes of aptitude: "unfavorable", "restricted" and "favorable", as shown in Table 3. 
Chart1. Parameters related to soil units in Tocantins (SEPLAN, 2012)

\begin{tabular}{|c|c|c|c|c|c|c|c|c|}
\hline Type of Soil & Fertility & Weight & Depth & Weight & Stoniness & Weight & Drainage & Weight \\
\hline $\begin{array}{c}\text { Rocky } \\
\text { Outcrops }\end{array}$ & (3) Low & 1 & (3)Unfavorable & 1 & ${ }^{(1)} \mathrm{High}$ & 1 & (1) Deficient & 1 \\
\hline $\begin{array}{c}\text { Haplic } \\
\text { Cambisols }\end{array}$ & ${ }^{(2)}$ Medium & 2 & ${ }^{(2)}$ Favorable & 5 & ${ }^{(2)}$ Low & 5 & ${ }^{(2)}$ Good & 5 \\
\hline Dunes & ${ }^{(1)}$ Low & 1 & ${ }^{(3)}$ Favorable & 5 & ${ }^{(3)}$ Low & 5 & ${ }^{(1)}$ Excessive & 1 \\
\hline $\begin{array}{c}\text { Petric } \\
\text { Plinthosols }\end{array}$ & (2) Low & 1 & (2)Unfavorable & 1 & ${ }^{(2)} \mathrm{High}$ & 1 & ${ }^{(2)}$ Good & 5 \\
\hline $\begin{array}{l}\text { Argiluvic } \\
\text { Plinthosols }\end{array}$ & ${ }^{(2)}$ Medium & 2 & (2)Unfavorable & 1 & (2) Low & 5 & ${ }^{(2)}$ Deficient & 1 \\
\hline $\begin{array}{c}\text { Haplic } \\
\text { Plinthosols } \\
\end{array}$ & ${ }^{\text {(2) Low }}$ & 1 & (2)Unfavorable & 1 & ${ }^{(2)} \mathrm{High}$ & 1 & ${ }^{(2)}$ Good & 5 \\
\hline $\begin{array}{c}\text { Haplic } \\
\text { Gleysols }\end{array}$ & (2) Low & 1 & (2)Unfavorable & 1 & ${ }^{(2)}$ Low & 5 & ${ }^{(2)}$ Deficient & 1 \\
\hline $\begin{array}{l}\text { Yellow } \\
\text { Latosols }\end{array}$ & ${ }^{(2)}$ Low & 2 & ${ }^{(2)}$ Favorable & 5 & (2) Low & 5 & ${ }^{(2)}$ Good & 5 \\
\hline $\begin{array}{c}\text { Red Latosols } \\
\text { (Oxisols) }\end{array}$ & ${ }^{\text {(2) Low }}$ & 2 & ${ }^{(2)}$ Favorable & 5 & (2) Low & 5 & ${ }^{(2)}$ Good & 5 \\
\hline $\begin{array}{c}\text { Red-Yellow } \\
\text { Latosols }\end{array}$ & ${ }^{(2)}$ Low & 2 & (2) Favorable & 5 & ${ }^{(2)}$ Low & 5 & ${ }^{(2)}$ Good & 5 \\
\hline $\begin{array}{c}\text { Argiluvic } \\
\text { Chernosols }\end{array}$ & (3) High & 5 & ${ }^{(1)}$ Unfavorable & 1 & (3) Low & 5 & ${ }^{(3)}$ Good & 5 \\
\hline Red Nitosols & (3) Low & 1 & ${ }^{(3)}$ Unfavorable & 1 & ${ }^{(3)}$ Low & 5 & ${ }^{(3)}$ Good & 5 \\
\hline $\begin{array}{l}\text { Yellow } \\
\text { Argisols }\end{array}$ & ${ }^{(2)}$ Low & 2 & ${ }^{(2)}$ Favorable & 5 & (2) Low & 5 & ${ }^{(2)}$ Good & 5 \\
\hline Red Argisols & (2)(3)Medium & 4 & ${ }^{(2)}$ Favorable & 5 & (2)Low & 5 & ${ }^{(2)}$ Good & 5 \\
\hline $\begin{array}{c}\text { Red-Yellow } \\
\text { Argisols }\end{array}$ & ${ }^{(2)}$ Low & 2 & ${ }^{(2)}$ Favorable & 5 & ${ }^{\text {(2) Low }}$ & 5 & ${ }^{(2)}$ Good & 5 \\
\hline $\begin{array}{l}\text { Litholic } \\
\text { Neosols }\end{array}$ & ${ }^{(2)}$ Low & 1 & (2)Unfavorable & 1 & (2) High & 1 & ${ }^{(2)}$ Good & 5 \\
\hline $\begin{array}{c}\text { Quartzipsamme } \\
\text { nts }\end{array}$ & ${ }^{(2)}$ Low & 1 & (2) Favorable & 5 & ${ }^{(2)}$ Low & 5 & ${ }^{(2)}$ Excessive & 1 \\
\hline Fluvisols & (2) Low & 1 & ${ }^{(2)}$ Favorable & 5 & (3) Low & 5 & ${ }^{(3)}$ Excessive & 1 \\
\hline $\begin{array}{c}\text { Natric } \\
\text { Planosols }\end{array}$ & (3) High & 5 & ${ }^{(3)}$ Favorable & 5 & ${ }^{(3)}$ Medim & 3 & ${ }^{(3)}$ Deficient & 1 \\
\hline $\begin{array}{c}\text { Haplic } \\
\text { Planosols } \\
\end{array}$ & (3) High & 5 & ${ }^{(3)}$ Favorable & 5 & ${ }^{(3)}$ Medium & 3 & ${ }^{(3)}$ Deficient & 1 \\
\hline Haplic Luvisols & (3) High & 5 & ${ }^{(3)}$ Unfavorable & 1 & (3) Low & 5 & ${ }^{(3)}$ Good & 5 \\
\hline
\end{tabular}

Source: ${ }^{(1)}$ Filho $(2011)^{(2)}$ Collicchio (2008) ${ }^{(3)}$ Embrapa Solos (2012)

Table 3. Classes of natural edaphic aptitude.

Classes of aptitude

Favorable

Regular

Unfavorable

The edaphic and climatic zoning for Eucalyptus urograndis resulted from the overlapping of agro-climatic with edaphic zoning. The

Condition (Result of the cross-checking of soil parameters)

Weight $>750$

$375 \leq$ Weight $\leq 750$

Weight $<375$ development of each one of these steps can be seen in Figure 2. 


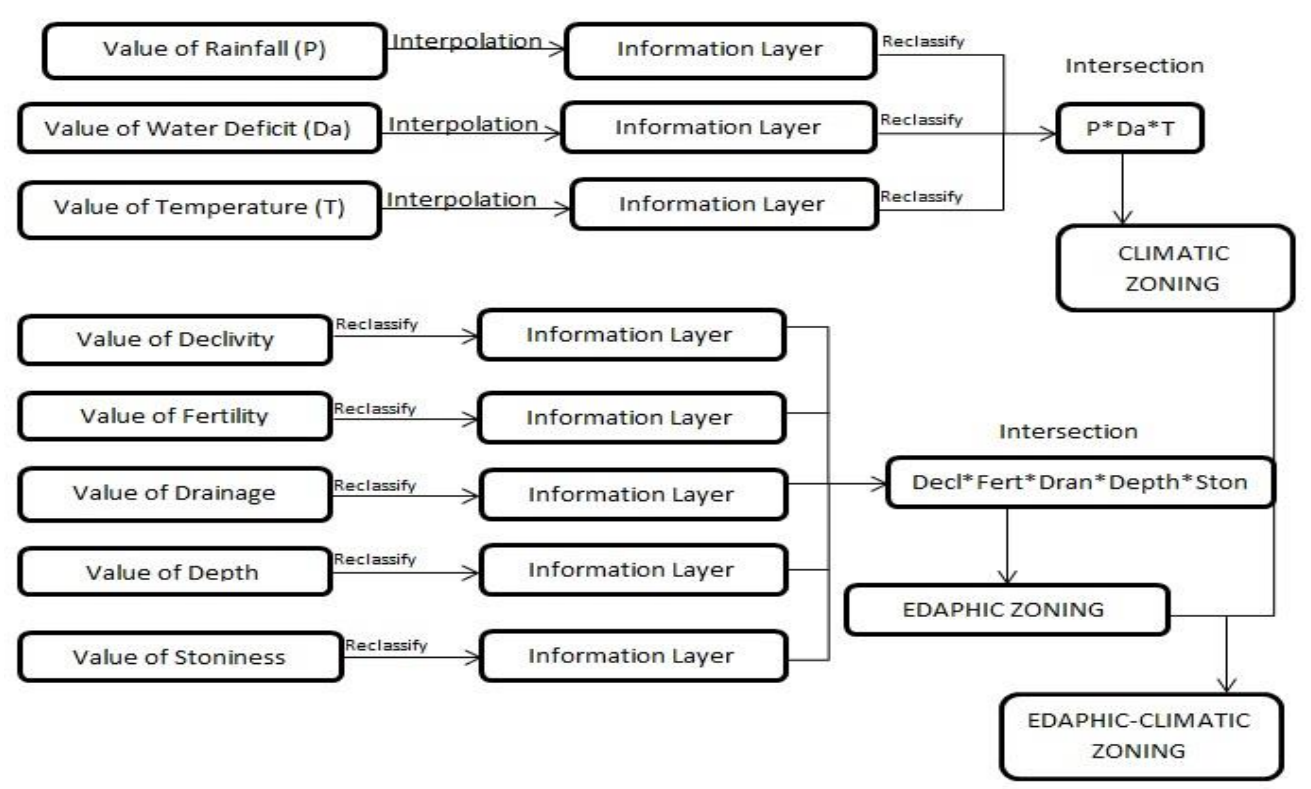

Figure 2. Flowchart of the steps of edaphic and climatic zoning of Eucalyptus urograndis.

\section{Results and Discussion}

The basic maps of annual average air temperature, annual water deficit and annual rainfall of the State of Tocantins, elaborated by Souza (2014), show a variation in the annual average temperature (Figure $3 a$ ), from $23^{\circ} \mathrm{C}$ to $27^{\circ} \mathrm{C}$, with a temperature range of $4^{\circ} \mathrm{C}$, and the annual average temperature is approximately $25.7^{\circ} \mathrm{C}$. The annual water deficit (Figure $\mathbf{3 b}$ ) of the State ranged from about $42 \mathrm{~mm}$ to $518 \mathrm{~mm}$, with a range of 476 $\mathrm{mm}$. The northwest region showed the lowest water deficit, which was within the threshold of favorable aptitude $(15<\mathrm{Da}<170 \mathrm{~mm})$.

Regarding rainfall (Figure $\mathbf{3 c}$ ), there was an annual average precipitation of approximately 821 $\mathrm{mm}$ to $2111 \mathrm{~mm}$. In this context, according to Sperandio et. al. (2010) there will be restrictions regarding temperature and rainfall for the cultivation of Eucalyptus urograndis in some regions of the State of Tocantins.

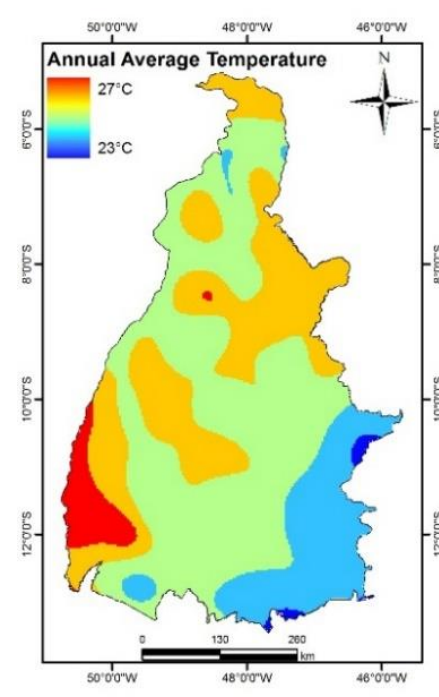

a)

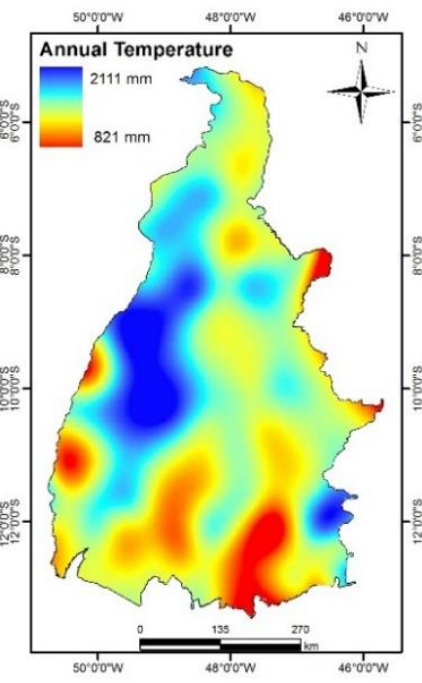

b)

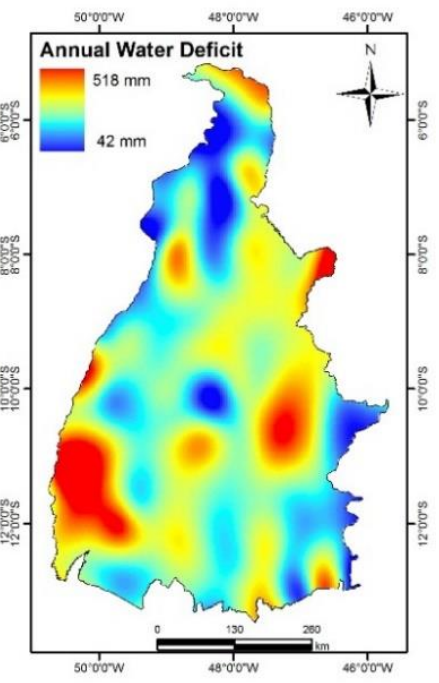

c)

Figure 3. Climatic parameters of the State of Tocantins: a) Annual average temperature $\left({ }^{\circ} \mathrm{C}\right)$, b) Annual water deficit ( $\mathrm{mm}$ ) and c) Annual rainfall (mm) (SOUZA, 2014).

The agro-climatic zoning for Eucalyptus urograndis in the State of Tocantins presented in
Figure 4 shows the existence of four possible classes of aptitude with different extensions. 
The class "apt" concerned areas fully suitable for cultivation, corresponding to $5,245.14 \mathrm{~km}^{2}$, and equivalent to approximately $1.89 \%$. The class of "marginal" aptitude corresponds to areas with aptitude for two climatic variables (in this case, temperature and precipitation), accounting for $16.33 \%\left(45,326.73 \mathrm{~km}^{2}\right)$ of the southeast area, occurring in a small portion of the northwest or the State. This indicates that water deficit is a limiting factor for the species under this condition.
In the area where only one of the climatic variables was considered "apt", aptitude was classified as "restricted", and comprised a large area of $171,678.56 \mathrm{~km}^{2}$ (61.84\%). Regarding the class "inapt"” it concerned an area of $55,369.58 \mathrm{~km}^{2}$ (19.94\%), occurring in a large portion of the northwest region of the State, since rainfall greater than $1.800 \mathrm{~mm}$ impair the development and economic production of the crop (SPERANDIO et al., 2010).

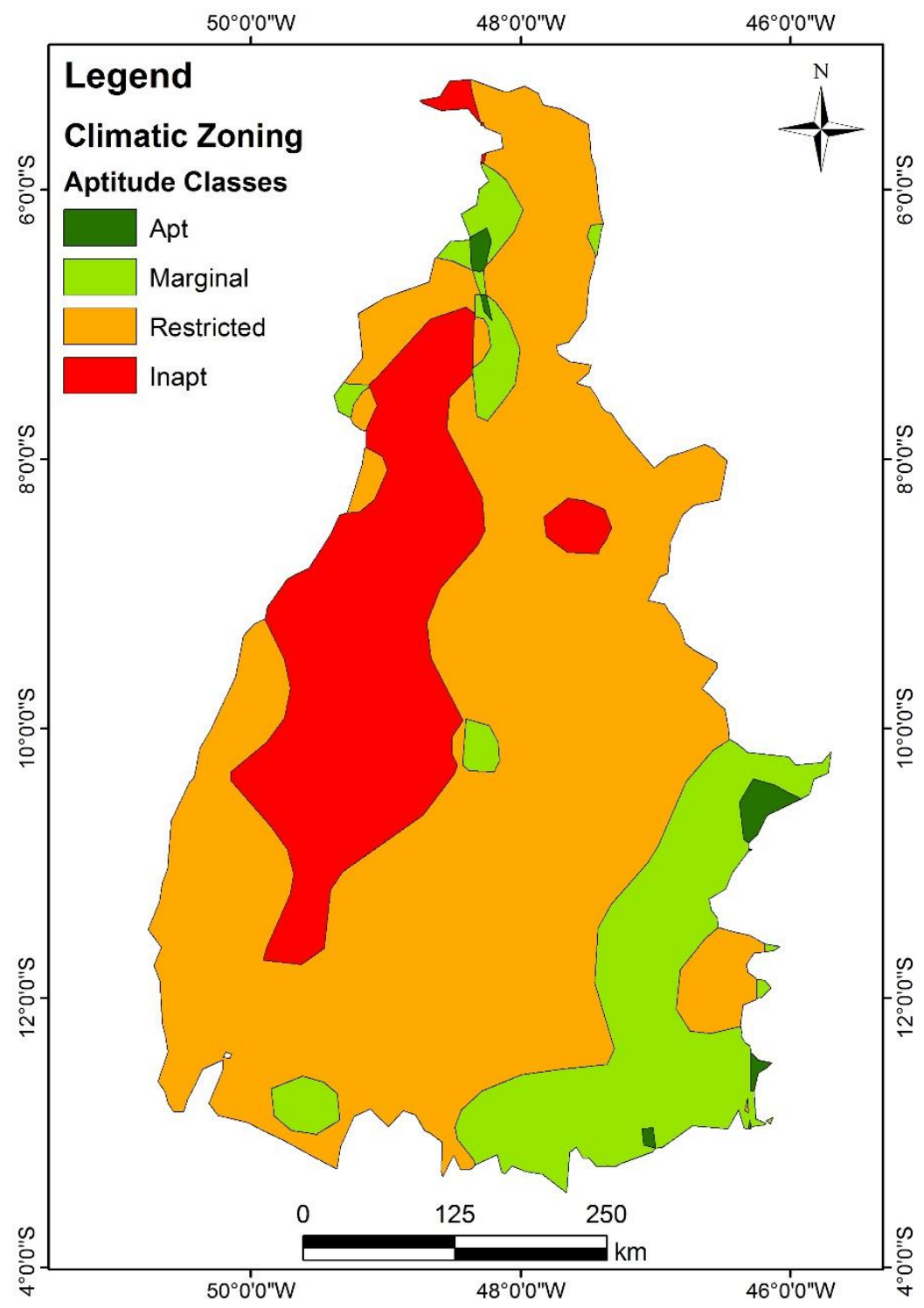

Figure 4. Agro-climatic zoning for Eucalyptus urograndis in the State of Tocantins.

The State of Tocantins is mostly composed of Plinthosols, Neosols and Latosols. Despite their significant fertility, Plinthosols and Neosols have stoniness and depth that do not favor the cultivation of eucalyptus, unlike the Latosols that have low fertility, but favorable depth and stoniness, which implies the need for soil conservation practices. With the cross-checking of such information (seen in Chart 1) we obtained the edaphic zoning that is presented in Figure $\mathbf{5}$. 


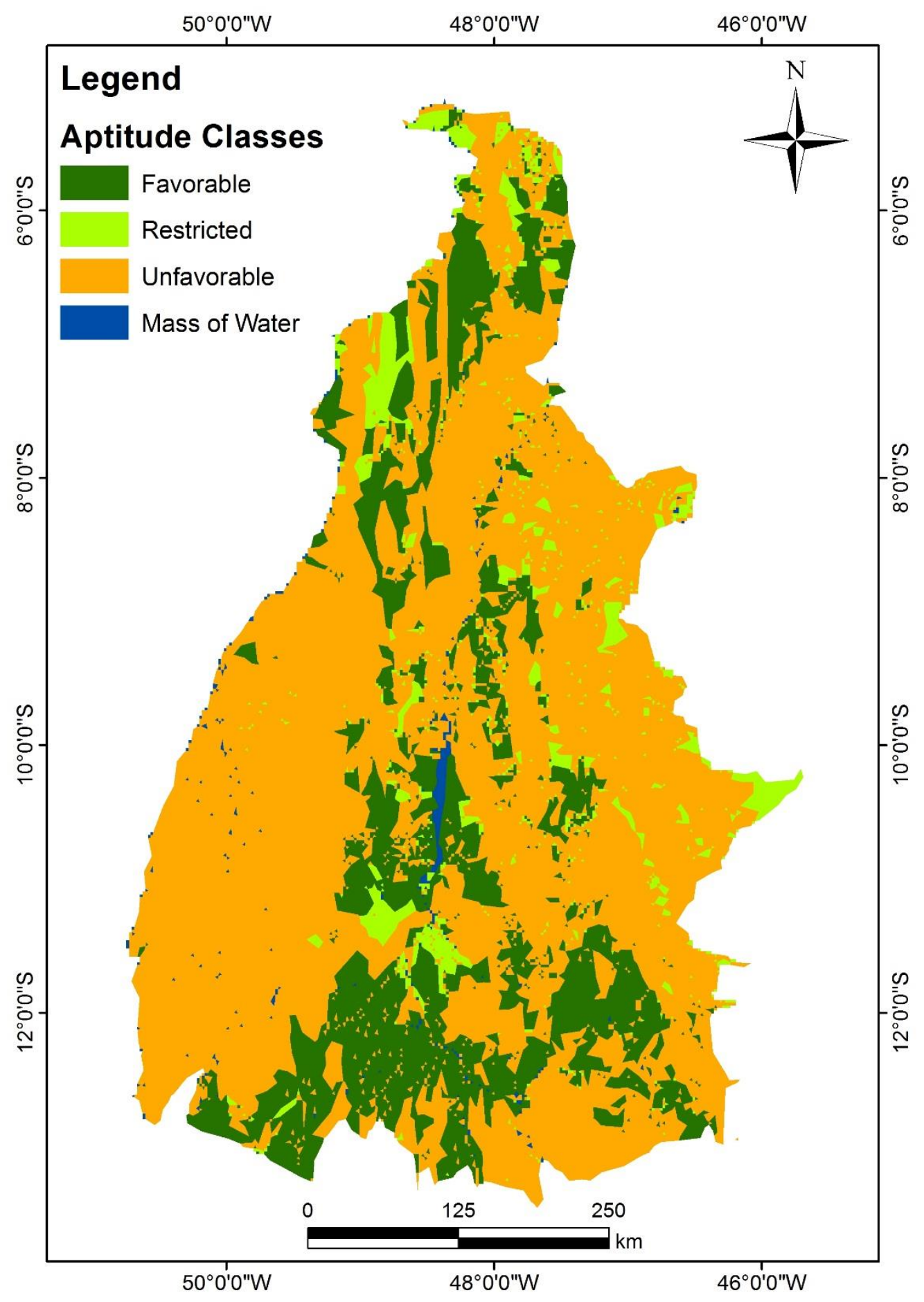

Figure 5. Natural edaphic zoning for Eucalyptus urograndis in the State of Tocantins.

It can be seen that the most favorable regions for agricultural production ("restricted" edaphic aptitude and "favorable" edaphic aptitude) are basically concentrated in the center: one area in the northwest and another in the south of the State. The area classified as "unfavorable" edaphic aptitude corresponded to the largest part of the State (68.36\%), equivalent to an area of $189.790,67 \mathrm{~km}^{2}$. Regarding "favorable" edaphic aptitude, it was found to be equivalent to $22.87 \%\left(63,478.36 \mathrm{~km}^{2}\right)$ and the area classified as "restricted" edaphic aptitude was the smallest part of the state $(6.65 \%)$, corresponding to $18.449,64 \mathrm{~km}^{2}$.

In edaphic and climatic zoning, the Eucalyptus urograndis (Figure 6) showed a percentage of area classified as "apt climate + favorable soil" of only de $0.61 \%$ for the State, corresponding to an area of $1,699.76 \mathrm{~km}^{2}$ in the cities of Ananás, Piraquê and Riachinho located in the micro-region of Bico do Papagaio. 


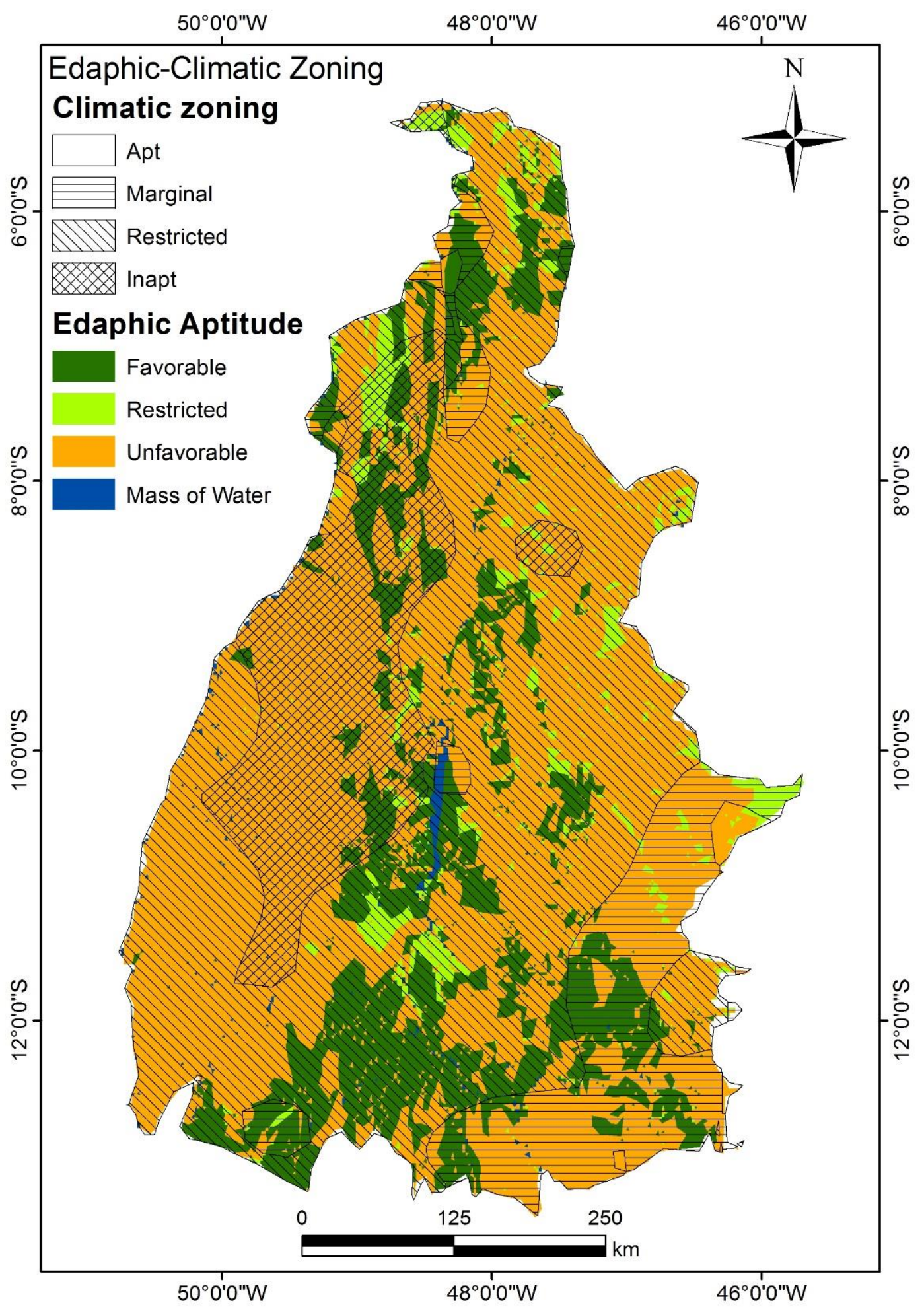

Figure 6. Edaphic and climatic zoning for Eucalyptus urograndis in the State of Tocantins.

To a lesser extent, the class "fit climate + restricted soil" obtained only $0.51 \%\left(1,424.42 \mathrm{~km}^{2}\right)$ of the total area, in the city of Mateiros to the east of the State. The class "marginal climate + favorable soil" equivalent to $4.79 \%\left(13,288.84 \mathrm{~km}^{2}\right)$ of the state's surface, comprising spatially dispersed areas of the micro-region of Dianópolis, to the South of the
State, including the cities of Araguaçu, Almas, Dianópolis and Conceição do Tocantins.

The species obtained the highest percentage of "Other conditions" with $92.99 \%\left(258,162.45 \mathrm{~km}^{2}\right)$, comprising the east, West and center of the State, which correspond to all the classes with unfavorable soil and inapt climate. These conditions represent an 
unfavorable environment for the cultivation of the species.

\section{CONCLUSIONS AND SUGGESTIONS}

The edaphic and climatic zoning shows that the Southern region of the State favors largely the class "marginal climate + favorable soil", inducing the cultivation of the species Eucalyptus urograndis, although in some regions this cultivation requires greater care.

The largest areas of eucalyptus plantations in Tocantins are located in the northern region of the State, in the micro-regions of Bico do Papagaio and Araguaína. However, both agro-climatic and edaphic zoning indicated that these regions have some restrictions to the cultivation of the referred species.
It should be stressed that analysis of the criteria in this study was performed according to the climatic requirements of the crop and considering the natural physical and chemical characteristics of the soil, disregarding any possible interference in crop management, in either planting, fertilization, soil correction, irrigation and specific techniques for managing the crop.

\section{ACKNOWLEDGMENTS}

To the LBA team in Tocantins (Partnership UFT/INPA), to Laboratório de Agroenergia, Uso da Terra e Mudanças Ambientais (LAMAM) da UFT and to Laboratório de Geoprocessamento da UFT, for support in the development of this study.

\section{REFERENCES}

CIB. Conselho de Informações sobre Biotecnologia. Eucalipto: oportunidades para um desenvolvimento sustentável. 2008. 20p.

COLLICCHIO, E. Zoneamento edafoclimático e ambiental para a cana-de-açúcar e as implicações das mudanças climáticas no estado do Tocantins. 2008. 157 f. (Tese de Doutorado em Ecologia Aplicada). Escola Superior de Agricultura "Luiz de Queiroz" - Universidade de São Paulo, Piracicaba, 2008.

EMBRAPA. Proposta de atualização da segunda edição do Sistema Brasileiro de Classificação de Solos - Ano 2012. Rio de Janeiro: Embrapa Solos, 2012. 59 p.

FILHO, J. C. A. Relação solo e paisagem no bioma caatinga. In: Simpósio Brasileiro de Geografia Física Aplicada, 14, Recife, 2011. Anais... Recife, PE, SBGFA. 2011. 24 p.

IBGE. 2012. Instituto Brasileiro de Geografia e Estatística. Resultado do Censo 2010. Disponível em: <http://www.ibge.gov.br/estadosat/perfil.php?sigla=to> . Acessado em: 10/02/2013.

MORA, A. L.; GARCIA, C. H. A Cultura do eucalipto no Brasil. São Paulo: Sociedade Brasileira de Silvicultura, 2000. 114 p.

NAPPO, M. E.; NAPPO, A. E.; PAIVA, H. N. de. Zoneamento ecológico de pequena escala para nove espécies arbóreas de interesse florestal no Estado de Minas Gerais. Revista Científica Eletrônica de Engenharia Florestal. v.5, p.1-14, 2005.

NEVES, J. C. L. Produção e partição de biomassa, aspectos nutricionais e hídricos em plantios clonais de

J. Bioen. Food Sci., v. 2, n.2: p.62-71, 2015 eucalipto na região litorânea do Espírito Santo. 2000. 202 f. (Tese de Doutorado). Universidade do Norte Fluminense - UENF, Campos dos Goytacazes. 2000.

PEREIRA, A. R. Agrometeorologia: simplificando o balanço hídrico de Thornthwaite - Mather. Revista Bragantia, Campinas, v. 64, n. 2, 2005. p. 311- 313, 2005.

RESIS, M. G. F.; KIMINS, J. P. REZENDE, G. C; BARROS, N. F. Acúmulo de biomassa em uma sequencia de idade de Eucalyptus grandis plantado no cerrado em duas áreas com diferentes produtividades. Revista Árvore, v. 9, n. 2, 1985. p.149-162.

SEPLAN. Secretaria de Planejamento e da Modernização da Gestão Pública. Atlas do Tocantins: subsídios ao planejamento da gestão territorial. Palmas, TO. 2012a. $80 p$.

- Secretaria de Planejamento e da Modernização da Gestão Pública. Mapas e atlas: base de dados geográficos. Palmas, TO. 2012b.

. Secretaria de Planejamento e da Modernização da Gestão Pública. Projeto de Gestão Ambiental Integrada - Bico do Papagaio: Zoneamento Ecológico-Econômico. Solos. Palmas: SEPLAN, 2004, 96 p.

SILVA, P. H. M.; BRITO, J. O.; JUNIOR, F. G. S. Potential of eleven Ecalyptus species for the production of essential oils. ScientiaAgricola. Piracicaba, v.63, n.1, p.85-90, jan./feb. 2006.

SOUZA, O. M. M. Zoneamento edafoclimático para cultura do eucalipto (Eucalyptus spp. e Corymbia sp.) no estado do Tocantins. 2014. 50 f. (Trabalho de conclusão

$$
70 \text { | P a g e }
$$


de graduação em Engenharia Ambiental). Universidade Federal do Tocantins, Palmas, TO. 2014.

SPERANDIO, H. V.; CAMPANHARO, W. A.; CECILIO, R. A.; NAPPO, M. E. Zoneamento Agroecológico para espécies de eucalipto no Estado do Espírito Santo. Caminhos de Geografia, Uberlândia. v. 11, n. 34, p. 203-216, jun. 2010.
STAPE, J. L.; GOMES, A. N. 1996. Influência dos estresses hídricos e nutricionais no crescimento de plantios de eucaliptos no nordeste do Brasil. In: Congresso Latino Americano de Ciência do Solo, 10, Águas de Lindóia, 1996. Anais... Águas de Lindóia, SBCS, v. 1.

THORTHWAITE, C. W.; MATHER, J. R. The water balance. New Jersey: Drexel Institute of Technology. 1955. 104p. 